\title{
Mutagenic Potential of Artificial Athletic Field Crumb Rubber at Increased Temperatures
}

MICHAEL J. DORSEY ${ }^{2}$, ELIZABETH ANDERSON ${ }^{2}$, OLIVIA ARDO ${ }^{2}$, MAX CHOU $^{2}$, EDWARD FARROW ${ }^{2}$, ETHAN L. GLASSMAN ${ }^{2}$, MARGARET MANLEY², HERBERT MEISNER'2, CECILY MEYERS'2, NOLAN MORLEY², JOSEPH ROMINGER², MADISON SENA², MADISON R. STIEFBOLD², BENJAMIN STITES², MAXWELL TASH², EMMA WEBER² and PATRICK E. COUNTS', Science Department, Wyoming High School, 106 Pendery Avenue, Cincinnati, Ohio, USA

ABSTRACT. Rubber tires contain several compounds that are known or suspected carcinogens. Many carcinogens are mutagens (Griffiths et al. 2000), and fluctuation assays based on the Ames test can be used as an initial screen for mutagenic potential. Granulated crumb rubber from recycled tires is commonly used in the creation of artificial athletic fields, and the surface temperature of these fields can reach levels far above the ambient temperature. In this study, crumb rubber samples taken directly from four separate artificial athletic field surfaces were used to make leachates using water at different temperatures. For each of these fields, leachates obtained in water at $70^{\circ} \mathrm{C}$ showed significant mutagenic potential $(p \leq .001)$ in Salmonella typhimurium fluctuation assays. Leachates obtained in water at $40^{\circ} \mathrm{C}$ showed no mutagenic potential for any of the fields tested. For one field, crumb rubber heated in water at temperatures as low as $50^{\circ} \mathrm{C}$ resulted in significant mutagenic potential $(p \leq 0.001)$. Water used in an experiment designed to mimic the irrigation of an artificial athletic field also showed mutagenic potential $(p \leq 0.001)$ in a fluctuation assay. These results suggest that at the higher temperatures such as those on artificial athletic field surfaces, the crumb rubber infill on these artificial athletic fields can become the source of a water soluble agent with mutagenic potential in bacteria.

\section{INTRODUCTION}

The replacement of natural grass athletic fields with artificial athletic fields has become increasingly common. Artificial fields are durable, require less maintenance and are often viewed as more cost effective (Claudio 2008; Cheng et al. 2014). Materials commonly used in artificial athletic fields include crumb rubber, small rubber pellets made from recycled tires (Claudio 2008; Beausoleil et al. 2009) which can be found at the field surface among the synthetic blades. Several groups have addressed the leaching of elements and organic compounds from recycled shredded rubber mulches or granulates and identified a low level of a wide range of metals and organic compounds including known or suspected carcinogens such as polycyclic aromatic hydrocarbons, lead and chromium (Bocca et al. 2009; Kanematsu et al. 2009; Li et al. 2010; Pavilonis et al. 2013). Some studies have suggested that the use of recycled tires in both athletic fields (Pavilonis et al. 2013) and playgrounds (Birkholz et al. 2003) is generally safe. Oth-

${ }^{1}$ Michael J. Dorsey and Patrick E. Counts are faculty members at Wyoming High School. Address correspondence to Dorsey at Wyoming High School, 106 Pendery Ave., Cincinnati, OH 45215. E-mail:dorseym@wyomingcityschools. org

${ }^{2}$ Advanced Placement Biology students ers have raised concern over using recycled tires in playgrounds (Llompart et al. 2013), and one report (Brown et al. 2007) recommended a moratorium on the installation of new artificial athletic fields and playgrounds that use rubber from recycled tires.

Many carcinogens are mutagens (Griffiths et al. 2000), and one technique commonly used to initially determine the potential mutagenicity of a substance is the Ames test (Ames et al. 1975) or fluctuation test (Luria and Delbruck 1943; Hubbard et al. 1984). These tests expose Salmonella typhimurium strains that are histidine heterotrophs to the substance in question and assay for histidine autotroph mutants. A significant increase in the number of histidine autotrophs among cells exposed to potential mutagen compared to the number of spontaneous histidine autotroph mutants indicates that a substance has mutagenic potential. S. typhimurium strain TA100 specifically requires a base-pair substitution to become autotrophic for histidine (McCann et al. 1975).

Birkholtz et al. (2003) extracted playground tire crumb with dichloromethane and DMSO and found no genotoxicity using fluctuation assays with various bacterial strains, including TA100, in the absence of S9 liver activation extract, which can convert some 
agents without mutagenic potential to agents with mutagenic potential. They concluded that the marginal toxicity seen in some samples with S9 extract were not at the level required to be considered genotoxic. These same authors also tested environmental toxicity of leachates made from tire mulch in water and reported toxicity to all aquatic organisms tested, however this activity disappeared after aging the tire mulch for three months (Birkholz et al. 2003).

Temperatures of artificial athletic fields have been reported to reach levels far above ambient temperatures as well as the temperatures of natural turf fields under the same conditions (Claudio 2008; Jia et al. 2007; McNitt et al. 2007; Williams and Pulley 2002). Williams and Pulley (2002) noted that an artificial athletic field in Utah reached temperatures as high as $93^{\circ} \mathrm{C}$ on a day when the air temperature was $37^{\circ} \mathrm{C}$. These same authors also noted that irrigation of a field quickly reduced the surface temperature from $78^{\circ} \mathrm{C}$ to $29^{\circ} \mathrm{C}$, but that the surface temperature rebounded to $73^{\circ} \mathrm{C}$ in only twenty minutes. McNitt et al. (2007) directly measured the surface temperature of several synthetic turf system test plots in Pennsylvania and found surface temperatures ranging from $53.8^{\circ} \mathrm{C}$ to $71.5^{\circ} \mathrm{C}$. Eight of these test plots were irrigated and the surface temperature of each was quickly reduced; the surface temperature also rebounded to various extents, but not as dramatically as seen in earlier studies. These authors concluded that the benefits of irrigation would vary partly on weather and light conditions (McNitt et al. 2007).

In this study, leachates made with crumb rubber infill collected directly from the surfaces of four separate artificial athletic fields (fields A through D) were assayed for mutagenic potential with fluctuation tests. The approximate age in years of fields $A$, $\mathrm{B}, \mathrm{C}$, and $\mathrm{D}$ were nine, four, two and less than one, respectively. In order to determine if the increase in temperature reported for artificial athletic fields may have a role in releasing mutagenic compounds from the infill, leachates were made at a range of temperatures. In order to mimic conditions that might be obtained on a field, that is, rain or irrigation, leachates were made using distilled water and no organic solvents.

\section{MATERIALS AND METHODS Collection of crumb rubber infill samples}

The four artificial athletic fields used in this study were all in the Cincinnati, Ohio, area and were chosen for no particular reason other than their accessibility. Infill samples were collected directly at random locations from the surface of each field by scraping the field surface by hand and collecting dislodged crumb rubber that fell onto a nearby piece of paper. Crumb rubber was then separated by hand, primarily with tweezers, from artificial grass, other substrate particles and larger organic materials.

\section{Leachate preparations}

In all leachate preparations, $25 \mathrm{~g}$ of crumb rubber were mixed with $50 \mathrm{ml}$ of distilled water, heated in a water bath at the indicated temperature for thirty minutes and then allowed to cool. The resulting solutions were filtered through 0.2 micron sterile filters and kept at room temperature until used in the fluctuation assay the next day.

\section{Fluctuation assays}

Each of the three fluctuation experiments was performed using a separate Muta-Chrome Plate Basic Kit supplied with TA100 cells (Environmental BioDetection Products, Inc., Canada) and therefore each experiment was carried out with a different culture of TA100 cells. On the day of an experiment, all required components were mixed into culture tubes provided as directed by the manufacturer, then 18.2 $\mathrm{ml}$ of sterile water or the solution to be tested was added. At this point, before adding TA100 cells, 200 $\mu \mathrm{l}$ of each mixture to be tested were added to eight microtiter wells of a single control plate. This ensured that there was no bacterial contamination of the solution prior to adding TA100 cells, and that there were no unforeseen chemical reactions occurring upon incubation at $37^{\circ} \mathrm{C}$ that would give false positive results. S. typhimurium TA100 cells were grown in the media provided for 17 to 18 hours, as directed by the kit instructions, before performing the assay. After dispensing aliquots to the no cell control microtiter plate, $5 \mu \mathrm{l}$ of the TA100 cell culture were added to each culture tube containing the required mixed components and the solution to be tested. No S9 activation enzyme extract was used in the fluctuation assays presented here. Next, 200 $\mu \mathrm{l}$ were dispensed into each of 96 wells of a microtiter plate. Plates were incubated in a sealed, zip lock plastic bag (the positive control plate was kept in its own bag, separate from the other plates), incubated at $37^{\circ} \mathrm{C}$ and scored after five to seven days. In this assay, a color change from blue to yellow in any mi- 
crotiter well is treated as a single reversion event. The number of reversions on an experimental plate compared to the number of spontaneous reversions on the water only (no mutagen) plate is used to determine the statistical significance (Gilbert 1980).

\section{Generation of eluates}

In the final experiment, $10 \mathrm{~g}$ of field $\mathrm{B}$ crumb rubber sample were placed in a $50 \mathrm{ml}$ polypropylene centrifuge tube creating a column approximately $5 \mathrm{~cm}$ tall. A Vernier Direct-Connect Temperature Probe was placed through a hole in the lid and connected to a computer via a LabQuest Mini interface to monitor the temperature using LoggerPro (version 3.8.6.2) software. The tube with the sample and probe was placed in a water bath until the measured temperature rose slightly above $70^{\circ} \mathrm{C}$. The tube was removed from the water bath and a small hole was punched in the bottom of the tube. When the temperature dropped to $70^{\circ} \mathrm{C}, 20 \mathrm{ml}$ of room temperature distilled water were added dropwise. The eluate was collected, the hole was plugged and the tube was placed back into the water bath until the temperature again reached $70^{\circ} \mathrm{C}$. It was then removed from the water bath and an additional $20 \mathrm{ml}$ of room temperature distilled water were added dropwise. The second eluate was collected in a new tube. The total time elapsed from the start of adding the water for the first eluate to the end of the collection of the second eluate was approximately 18 minutes. Both eluates were then sterile filtered, stored overnight at room temperature and assayed as above. Crumb rubber from field B was used here because it showed the greatest mutagenic potential in the fluctuation assays and thus had the greatest chance of showing positive results in this assay.

\section{RESULTS}

Table 1 shows the results of four independent fluctuation experiments. For each experiment, the number of reversions obtained with the positive control (sodium azide) is indicated as well as any significant difference to the water only control as described in Gilbert (1980). In experiment 1, leachates from field A crumb rubber showed significant mutagenic potential with the $60^{\circ} \mathrm{C}(\mathrm{p} \leq 0.01)$ and $85^{\circ} \mathrm{C}(\mathrm{p} \leq$ 0.01 ) samples but not the $50^{\circ} \mathrm{C}$ sample. A preliminary fluctuation assay had indicated significant ( $\mathrm{p} \leq$ 0.001 ) mutagenic potential of a field A crumb rubber leachate made at $100^{\circ} \mathrm{C}$ (data not shown). Only eight reversions were detected in the microtiter plate used to assay the leachate made at $100^{\circ} \mathrm{C}$ for experiment 1 (Table 1), which was well below the 24 reversions obtained in this experiment with water alone. A ten-fold dilution of the same leachate sample was tested in experiment 2 , approximately 30 days later. This diluted sample resulted in significant mutagenicity ( $\mathrm{p} \leq 0.05$; Table 1$)$.

Crumb rubber leachates made at $40^{\circ} \mathrm{C}$ from fields $\mathrm{A}, \mathrm{B}, \mathrm{C}$ and $\mathrm{D}$ showed no significant increase in mutagenicity (Table 1). However, leachates made at $70^{\circ} \mathrm{C}$ from each of the four field samples showed significant mutagenicity $(\mathrm{p} \leq .001)$. In addition, a series of fluctuation tests was performed on field B crumb rubber leachates made at temperatures of $40^{\circ} \mathrm{C}$, $50^{\circ} \mathrm{C}, 55^{\circ} \mathrm{C}, 60^{\circ} \mathrm{C}$ and $70^{\circ} \mathrm{C}$. For these assays, crumb rubber was collected a second time from the surface of field B. Leachates made at each of these temperatures, except for $40^{\circ} \mathrm{C}$, resulted in significant mutagenicity $(\mathrm{p} \leq 0.001)$.

Figure 1 shows the recorded temperature of a sample of crumb rubber from field B as distilled water was added dropwise and allowed to filter through a $5 \mathrm{~cm}$ column of the sample. The temperature of the sample decreased from $70^{\circ} \mathrm{C}$ to $30^{\circ} \mathrm{C}$ during the first five minutes as the first eluate was collected. The temperature was allowed to recover to $70^{\circ} \mathrm{C}$ at which

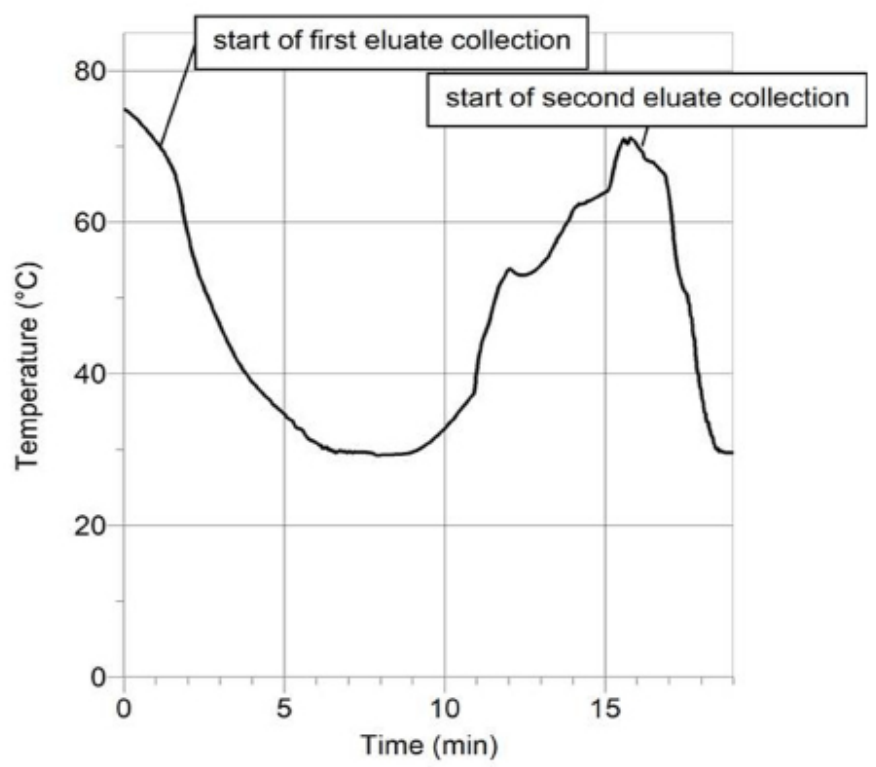

FIGURE 1. Temperature profile of crumb rubber during generation of eluates with room temperature distilled water. Each eluate was generated by adding $20 \mathrm{ml}$ distilled water dropwise to a column of crumb rubber first preheated to $70^{\circ} \mathrm{C}$. After the first eluate was collected, the now moistened crumb rubber column was reheated, and the second $20 \mathrm{ml}$ was collected. The time point where the water addition began for each eluate is indicated. 
TABLE 1

Results of fluctuation assays for three separate experiments

\begin{tabular}{|c|c|c|c|c|c|}
\hline Experiment & Sample & Field & $\begin{array}{l}\text { Treatment } \\
\text { Temperature }\end{array}$ & $\begin{array}{l}\text { Number of positive wells } \\
\text { (percent of total, } N=96 \text { ) }\end{array}$ & p value ${ }^{1}$ \\
\hline 1 & water plus sodium azide & & Room temp & $81(84 \%)$ & $\mathrm{p} \leq 0.001$ \\
\hline 1 & water only & & Room temp & $24(25 \%)$ & -- \\
\hline 1 & crumb rubber leachate & A & $100^{\circ} \mathrm{C}$ & $8(8 \%)$ & -- \\
\hline 1 & crumb rubber leachate & A & $85^{\circ} \mathrm{C}$ & $42(44 \%)$ & $\mathrm{p} \leq 0.01$ \\
\hline 1 & crumb rubber leachate & A & $60^{\circ} \mathrm{C}$ & $41(43 \%)$ & $\mathrm{p} \leq 0.01$ \\
\hline 1 & crumb rubber leachate & A & $50^{\circ} \mathrm{C}$ & $22(23 \%)$ & \\
\hline 2 & water plus sodium azide & & Room temp & $77(80 \%)$ & $\mathrm{p} \leq 0.001$ \\
\hline 2 & water only & & Room temp & $8(8 \%)$ & -- \\
\hline 2 & crumb rubber leachate & A & $70^{\circ} \mathrm{C}$ & $91(95 \%)$ & $\mathrm{p} \leq 0.001$ \\
\hline 2 & crumb rubber leachate & A & $40^{\circ} \mathrm{C}$ & $3(3 \%)$ & -- \\
\hline 2 & crumb rubber leachate & $\mathrm{B}$ & $70^{\circ} \mathrm{C}$ & $96(100 \%)$ & $\mathrm{p} \leq 0.001$ \\
\hline 2 & crumb rubber leachate & $\mathrm{B}$ & $40^{\circ} \mathrm{C}$ & $14(15 \%)$ & -- \\
\hline 2 & crumb rubber leachate & $\mathrm{C}$ & $70^{\circ} \mathrm{C}$ & $64(67 \%)$ & $\mathrm{p} \leq 0.001$ \\
\hline 2 & crumb rubber leachate & $\mathrm{C}$ & $40^{\circ} \mathrm{C}$ & $9(9 \%)$ & -- \\
\hline 2 & $1 / 10$ of $100^{\circ} \mathrm{C}$ sample in exp 1 & A & -- & $18(19 \%)$ & $\mathrm{p} \leq 0.05$ \\
\hline 3 & water plus sodium azide & & Room temp & $46(48 \%)$ & $\mathrm{p} \leq 0.01$ \\
\hline 3 & water only & & Room temp & $28(29 \%)$ & -- \\
\hline 3 & crumb rubber leachate & B & $70^{\circ} \mathrm{C}$ & $56(58 \%)$ & $\mathrm{p} \leq 0.001$ \\
\hline 3 & crumb rubber leachate & B & $60^{\circ} \mathrm{C}$ & $96(100 \%)$ & $\mathrm{p} \leq 0.001$ \\
\hline 3 & crumb rubber leachate & $\mathrm{B}$ & $55^{\circ} \mathrm{C}$ & $96(100 \%)$ & $\mathrm{p} \leq 0.001$ \\
\hline 3 & crumb rubber leachate & $\mathrm{B}$ & $50^{\circ} \mathrm{C}$ & $95(99 \%)$ & $\mathrm{p} \leq 0.001$ \\
\hline 3 & crumb rubber leachate & $\mathrm{B}$ & $40^{\circ} \mathrm{C}$ & $17(18 \%)$ & \\
\hline
\end{tabular}




\section{TABLE 1 (cont.) \\ Results of fluctuation assays for three separate experiments}

\begin{tabular}{cccccc}
\hline \hline Experiment & Sample & Field & $\begin{array}{c}\text { Treatment } \\
\text { Temperature }\end{array}$ & $\begin{array}{c}\text { Number of positive wells } \\
\text { (percent of total, N = 96) }\end{array}$ & p value $^{1}$ \\
\hline 3 & crumb rubber leachate & $\mathrm{D}$ & $70^{\circ} \mathrm{C}$ & $96(100 \%)$ & $\mathrm{p} \leq 0.001$ \\
3 & crumb rubber leachate & $\mathrm{D}$ & $40^{\circ} \mathrm{C}$ & $20(21 \%)$ & \\
3 & eluate 1 & $\mathrm{B}$ & $70^{\circ} \mathrm{C}$ & $22^{2}(23 \%)$ & $\mathrm{p} \leq 0.001$ \\
3 & eluate 2 & $\mathrm{B}$ & $70^{\circ} \mathrm{C}$ & $96(100 \%)$ &
\end{tabular}

${ }^{1}$ Determination of $\mathrm{p}$ values is described in Gilbert, 1980. The $\mathrm{p}$ value reflects the probability that the deviation between the number of positive wells for the sample and the number of positive wells for the water only control is due only to chance.

${ }^{2}$ This sample received $10 \mu \mathrm{l}$, rather than $5 \mu$, of TA100 cells and thus would be expected to have twice the number of spontaneous reversions than the water only control.

point the second application of water again rapidly decreased the temperature. When tested in fluctuation assays, the first eluate resulted in only a slightly lower number of positive wells than the spontaneous reversion plate. However, this sample inadvertently received 10 $\mu \mathrm{l}$, rather than $5 \mu \mathrm{l}$, of TA100 cells and thus would be expected to have twice the background of spontaneous reversions than the water only control. If $5 \mu$ of cell culture had been added, the expected number of background reversions would be approximately 28 , the number seen for the water only control (Table 1 , Experiment 3, water only). Since $10 \mu \mathrm{l}$ of cells were added, around 56 background reversions would have been expected, or twice the number seen with the water only control. However, only 22 reversions were observed from the assay of this sample. Had only $5 \mu \mathrm{l}$ of cells been used, it would have been expected that only around one-half of these reversions, or 11, would have been observed. Given this lower than expected number of reversions detected when assaying eluate 1 , the sample concentration tested may have been toxic. The second eluate, with only $5 \mu$ of TA 100 cell culture used during the assay, showed significant mutagenic potential $(\mathrm{p} \leq 0.001$; Table 1$)$.

\section{DISCUSSION}

Many studies have been done on the chemical composition of crumb rubber and the possible ad- verse health effects associated with artificial athletic fields which use it in part as a means of softening the surface (Cheng et al. 2014). Recycled tires used either in the production of crumb rubber or in rubber mulches for playgrounds have been shown to contain a variety of organic compounds (Sullivan 2006; Li et al. 2010; Menichini et al. 2011). Risk assessment studies evaluating the potential exposure to many of these organic compounds have suggested that the associated health risk is minimal (Beausoleil et al. 2009; Menichini et al. 2011; Pavilonis et al. 2013). Numerous inorganic compounds and metals, especially zinc, but also lead, chromium, copper, nickel, arsenic and cadmium are also present in recycled tires (Bocca et al. 2009; US EPA 2009; Li et al. 2010; Menichini et al. 2011). Lead, nickel, arsenic, cadmium and chromium, or their compounds, are all known or suspected mutagens or carcinogens (Leonard and Lauwerys 1980; Arlauskas et al. 1985; Silbergeld et al. 2000; Das et al. 2008; IARC 2015), whereas zinc is not a known mutagen (Leonard et al. 1986). Nestmann et al. (1979) used bacterial reversion assays in concluding that the mutagenicity of lead chromate was due to the chromate ion and not the lead ion. In conventional fluctuation assays, Arlauskas et al. (1985) showed that cadmium(II) and chromate(VI) were mutagenic while nickel(II) and arsenate(V) were not, even though these are known to be mutagenic in 
other systems. Again, it is important to note that the agents showing mutagenic potential detected in the leachates prepared here must be at least partly water soluble. No DMSO or other organic solvents or treatments were used in generating the leachates. In addition, no S9 activation enzyme extract was used in the fluctuation assays presented here indicating the agent would not require enzymatic conversion from a pre-mutagenic substance.

A preliminary assay had indicated that leachates prepared at $100^{\circ} \mathrm{C}$ showed significant $(\mathrm{p} \leq 0.001)$ mutagenic potential (data not shown). A new leachate prepared at $100^{\circ} \mathrm{C}$ was used in experiment 1 , and this was diluted and assayed one month later in experiment 2. When assayed undiluted, this leachate resulted in fewer positive wells than the water only control (Table 1, Experiment 1), suggesting that the sample concentration may be toxic; when diluted ten-fold and retested one month later, it showed significant mutagenic potential $(\mathrm{p} \leq 0.05$; Table 1 , Experiment 2). Although different TA100 cell cultures were used to test these samples, and the results cannot be directly compared, it does suggest that the suspected agent is not highly volatile and is stable in an aqueous solution for at least this time frame.

The leachates used in this study were made at higher temperatures for only 30 minutes. Furthermore, for the experiment designed to mimic field irrigation, the time to collect each of the eluates as water was filtered over $70^{\circ} \mathrm{C}$ crumb rubber was around four to five minutes for each with no more than 10 minutes of heating between the two sample collections. This suggests that the temperature of the crumb rubber, especially above $40^{\circ} \mathrm{C}$, and not exposure to water for extended lengths of time, may be more important in considering "worst-case scenarios" in future testing.

Not surprisingly, some variability in mutagenicity is seen among the four fields tested in this study. For example, field $\mathrm{B}$ leachates produced at $50^{\circ} \mathrm{C}$ showed mutagenic potential while those produced from field $\mathrm{A}$ at $50^{\circ} \mathrm{C}$ did not. This may be due to the variability seen in the composition of tires (Sullivan 2006; US EPA 2009). The ages of the fields tested here ranged from less than one year to nine years old. However, because crumb rubber may have been replenished on any of the four playing surfaces, especially the older fields, it is not possible in this study to draw a correlation between the fluctuation assay results and the relative ages of the fields. It has been suggested that the aging of the recycled rubber would likely lessen the amount of any potentially harmful compounds that may leach from it over time (Birkholz et al. 2003). The study presented here did not address the amount of mutagenic potential over time for the same field. Nevertheless, this study does show that leachates made at $70^{\circ} \mathrm{C}$ with crumb rubber taken directly from the surfaces of four fields are capable of releasing water soluble substances having mutagenic potential in bacteria. Further studies would be needed to determine if the variability seen among fields is due to the relative age of the crumb rubber, the composition of the recycled tires used in making the crumb rubber, the weathering of the fields, or a combination of these or other factors.

Since these leachates were made from crumb rubber taken directly from field surfaces, and because artificial athletic fields may be periodically groomed and washed, the possibility that the agent with mutagenic potential detected in these experiments is from some external source cannot be entirely excluded. Because the suspected mutagen is reproducibly released with heating in water to $70^{\circ} \mathrm{C}$, and has not yet been detected in leachates made in water at $40^{\circ} \mathrm{C}$, it is reasonable to conclude that it is not readily washed off. It is therefore unlikely that the suspected agent is one that has been externally applied to the crumb rubber. Further studies are needed to elucidate the dynamics of temperature and water content of artificial athletic fields with respect to the potential release of agents with mutagenic potential.

The surface temperature that any particular artificial athletic field might reach will vary with season and regional climate. Williams and Pulley (2002) reported a high surface temperature of $93^{\circ} \mathrm{C}$ for an artificial athletic field in Utah on a day when the air temperature was $37^{\circ} \mathrm{C}$. These same authors reported an average field temperature on a day in June, 2002, of $47^{\circ} \mathrm{C}$ with a high of $69^{\circ} \mathrm{C}$. Irrigation systems are commercially available for maintenance of artificial athletic fields, and irrigation has been shown to have a marginal effect on lowering surface temperatures for up to several hours (Williams and Pulley 2002; Jia et al. 2007; McNitt et al. 2007). In this study, the results of the experiment designed to mimic water falling on a hot field surface (Figure 1 and Table 1, eluate 1 and eluate 2 ), where crumb rubber is readily found, suggests that compounds with mutagenic potential could enter solution upon irrigation of a field with a surface temperature of $70^{\circ} \mathrm{C}$, a temperature within the range reported by others (Williams and 
Pulley 2002; McNitt et al. 2007). Given that the leachate prepared at $50^{\circ} \mathrm{C}$ with field $\mathrm{B}$ crumb rubber produced a substance with significant mutagenic potential, fields with surface temperatures as low as $50^{\circ} \mathrm{C}$ may also fall into this category. Further studies would be needed to address this possibility or the possibility that rainwater may have a similar effect. A substance with mutagenic potential released after water falls onto a hot artificial athletic field would either drain away with the water or stay on the field surface. Risk assessment studies are needed to consider the health impact of repeated exposure to crumb rubber at the conditions relevant to artificial athletic fields.

\section{ACKNOWLEDGMENTS}

We thank Elizabeth J. Taparowsky, Ph.D., of Purdue University for insightful discussions, suggestions and encouragement and Environmental Bio-Detection Products, Inc., for suggestions. We thank Jennifer L. Counts, Ph.D., for reviewing the manuscript and making helpful suggestions. This work was partially supported by a PSA grant to Dorsey.

\section{LITERATURE CITED}

Ames BN, McCann J, Yamasaki E. 1975. Methods for detecting carcinogens and mutagens with the Salmonella/mammalianmicrosome mutagenicity test. Mutat Res 31(6):347-364.

Arlauskas A, Baker RS, Bonin AM, Tandon RK, Crisp PT, Ellis J. 1985. Mutagenicity of metal ions in bacteria. Environ Res 36(2):379-388.

Beausoleil M, Price K, Muller C. 2009. Chemicals in outdoor artificial turf: a health risk for users? Public Health Branch, Montreal Health and Social Services Agency. [accessed 2015 April 22]. http://www.ncceh.ca/sites/default/files/ Outdoor_Artificial_Turf.pdf.

Birkholz DA, Belton KL, Guidotti TL. 2003. Toxicological evaluation for the hazard assessment of tire crumb for use in public playgrounds. J Air Waste Manag Assoc 53(7):903-907.

Bocca B, Forte G, Petrucci F, Costantini S, Izzo P. 2009. Metals contained and leached from rubber granulates used in synthetic turf areas. Sci Total Environ 407(7):2183-2190. doi: 10.1016/j.scitotenv.2008.12.026

Brown D, Alderman N, Addiss S, Bradley J. 2007. Artificial turf: exposures to ground-up rubber tires - athletic fields, playgrounds, garden mulch. [accessed 2015 April 22] http:// www.ehhi.org/reports/turf/turf_report07.pdf.

Cheng H, Hu Y, Reinhard M. 2014. Environmental and health impacts of artificial turf: a review. Environ Sci Technol 48(4):2114-2129. doi: 10.1021/es4044193

Claudio L. 2008. Synthetic turf: health debate takes root. Environ Health Perspect 116(3):A116-A122.

Das KK, Das SN, Dhundasi SA. 2008. Nickel, its adverse health effects \& oxidative stress. Indian J Med Res 128(4):412-425.
Gilbert R. 1980. The analysis of fluctuation tests. Mutat Res Environ Mutagen Relat Subj 74(4):283-289.

Griffiths AJF, Miller JH, Suzuki DT, Lewontin RC, Gelbart WM. 2000. An introduction to genetic analysis. 7 th edition. New York: W. H. Freeman; Chapter 16, Mechanisms of gene mutation [accessed 2015 May 28]. http://www.ncbi.nlm. nih.gov/books/NBK21788/.

Hubbard S, Green MHL, Gatehouse D, Bridges J. 1984. The fluctuation test in bacteria. In: Kilbey BJ, editor. Handbook of mutagenicity test procedures. 2nd edition. Amsterdam: Elsevier/North Holland.

International Agency for Research on Cancer (IARC). 2015. IARC monographs on the evaluation of carcinogenic risks to humans. [accessed 2015 May 28]. http://monographs. iarc.fr/ENG/Classification/

Jia X, Dukes MD, Miller GL. 2007. Temperature increase on synthetic turf grass. In: Kabbes, KC, editor. Proceedings of the World Environmental and Water Resources Congress 2007: Restoring Our Natural Habitat. 2007 May 15-19; Tampa, Florida: ASCE. doi: http://dx.doi. org/10.1061/40927(243)240.

Kanematsu M, Hayashi A, Denison MS, Young TM. 2009. Characterization and potential environmental risks of leachate from shredded rubber mulches. Chemosphere 76(7):952-958. doi:10.1016/j.chemosphere.2009.04.026.

Leonard A, Gerber GB, Leonard F. 1986. Mutagenicity, carcinogenicity and teratogenicity of zinc. Mutat Res 168(3):343-353.

Leonard A, Lauwerys RR. 1980. Carcinogenicity and mutagenicity of chromium. Mutat Res 76(3):227-239.

Li X, Berger W, Musante C, Mattina MI. 2010. Characterization of substances released from crumb rubber material used on artificial turf fields. Chemosphere 80(3):279-285. doi: 10.1016/j.chemosphere.2010.04.021.

Llompart M, Sanchez-Prado L, Pablo Lamas J, Garcia-Jares C, Roca E, Dagnac T. 2013. Hazardous organic chemicals in rubber recycled tire playgrounds and pavers. Chemosphere 90(2):423-431. doi:10.1016/j.chemosphere.2012.07.053.

Luria SE, Delbruck M. 1943. Mutations of bacteria from virus sensitivity to virus resistance. Genetics 28(6):491-511.

McCann J, Spingarn NE, Kobori J, Ames BN. 1975. Detection of carcinogens as mutagens: bacterial tester strains with $\mathrm{R}$ factor plasmids. Proc Natl Acad Sci U S A 72(3):979-983.

McNitt A, Petrunak D, Serensits T. 2007. Temperature amelioration of synthetic turf surfaces through irrigation. [accessed 2015 April 23] http://plantscience.psu.edu/research/centers/ ssrc/documents/temperature-irrigation.pdf.

Menichini E, Abate V, Attias L, De Luca S, di Domenico A, Fochi I, Forte G, Iacovella N, Iamiceli AL, Izzo P et al. 2011. Artificial-turf playing fields: contents of metals, PAHs, PCBs, PCDDs and PCDFs, inhalation exposure to PAHs and related preliminary risk assessment. Sci Total Environ 409(23):4950-4957. doi: 10.1016/ j.scitotenv.2011.07.042.

Nestmann ER, Matula TI, Douglas GR, Bora KC, Kowbel DJ. 1979. Detection of the mutagenic activity of lead chromate using a battery of microbial tests. Mutat Res 66(4):357-365.

Pavilonis BT, Weisel CP, Buckley B, Lioy PJ. 2013. Bioaccessibility and risk of exposure to metals and SVOCs in artificial turf field fill materials and fibers. Risk Analysis 34(1):44-55. doi: $10.1111 /$ risa. 12081 .

Silbergeld EK, Waalkes M, Rice JM. 2000. Lead as a carcinogen: experimental evidence and mechanisms of action. Am J Ind Med 38(3):316-323. 
Sullivan JP. 2006. An assessment of environmental toxicity and potential contamination from artificial turf using shredded or crumb rubber. [accessed 2015 April 23]. http://www. ardeacon.com/pdf/Assessment_Environmental_Toxicity_Report.pdf.

US EPA. 2009. A scoping-level field monitoring study of synthetic turf fields and playgrounds. Washington (DC):US EPA. No. EPA/600/R-09/135. [accessed 2015 April 24]. http://www. epa.gov/nerl/download_files/documents/tire_crumbs.pdf.
Williams C, Pulley G. 2002. Synthetic surface heat studies. [accessed 2015 April 21]. http://cahe.nmsu.edu/programs/turf/ documents/brigham-young-study.pdf. 